\title{
PENGARUH MODEL PEMBELAJARAN PROBLEM SOLVING TERHADAP KEMAMPUAN BERFIKIR KREATIF MAHASISWA PADA MATA KULIAH GEOGRAFI PARIWISATA
}

\author{
Rosanti $^{1}$, Endah Evy Nurekawati ${ }^{2}$ \\ ${ }^{1,2}$ Program Studi Pendidikan Geografi \\ Fakultas Ilmu Pendidikan dan Pengetahuan Sosial IKIP PGRI Pontianak \\ Jalan Ampera Nomor 88 Pontianak - 78116, Telepon (0561) 748219 Fax. (0561) 589855 \\ ${ }^{1}$ Alamat e-mail: evy.tonie@gmail.com
}

\begin{abstract}
Abstrak
Tujuan penelitian ini adalah untuk mengetahui apakah ada pengaruh model pembelajaran problem solving terhadap kemampuan berfikir kreatif mahasiswa pada mata kuliah geografi pariwisata tahun akademik 2016/2017. Metode penelitiannya Quasi Experiment (Eksperimen Semu). Rancangan penelitian yang dipilih adalah Nonequivalent Control Group Design..Teknik pengumpulan data yang di pergunakan adalah pengukuran berupa tes dan dokumentasi. Berdasarkan hasil analisis data dan pembahasan hasil penelitian dapat disimpulkan bahwa penggunaan model pembelajaran Problem Solving memberikan pengaruh positif terhadap kemampuan berpikir kreatif mahasiswa. Hal ini dibuktikan dengan hasil perhitungan analisis uji t mengunakan independen sample t test diperoleh data p-level lebih kecil dari $0,05(\mathrm{p}<0,05)$ yaitu 0,00 . Rata-rata skor post test kelas eksperimen lebih tinggi dibandingkan kelas kontrol. Hal tersebut disebabkan oleh langkah-langkah model pembelajaran Problem Solving yang di dalamnya terdapat teknik-teknik belajar kreatif dari yang sederhana sampai yang kompleks. Selain itu faktor suasana dan proses pembelajaran di kelas juga mendukung hasil penelitian ini.
\end{abstract}

Kata kunci: problem solving, kemampuan berfikir kreatif, Geografi

\begin{abstract}
The purpose of this study is to determine whether there is influence of problem solving learning model on the ability of creative thinking of students in the geography of tourism academic year 2016/2017. Research methods Quasi Experiment (Pse experiments). The selected research design is Nonequivalent Control Group Design..Technique of data collection in use is measurement in the form of test and documentation. Based on the results of data analysis and discussion of research results can be concluded that the use of Problem Solving learning model gives a positive influence on students' creative thinking ability. This is evidenced by the results of t test analysis using independent sample t test obtained p-level data smaller than 0.05 ( $p$ <0.05) that is 0.00. The average post test score of the experimental class is higher than the control class. This is caused by the steps of Problem Solving learning model in which there are creative learning techniques from simple to complex. In addition the atmosphere factor and the learning process in the classroom also support the results of this study.
\end{abstract}

Keywords: problem solving learning model, student creative thinking ability, Geography

\section{PENDAHULUAN}


Geografi Pariwisata bagian dari sebaran mata kuliah Keahlian yang terdapat pada semester empat di Program Studi Pendidikan Geografi S1 IKIP PGRI Pontianak serta mengacu kepada Kurikulum Kerangka Kualifikasi Nasional Indonesia (KKNI). Mata kuliah ini membahas tentang pendekatan, teori dan konsep geografi dalam kepariwisataan dengan berbagai analisis dan aplikasi untuk menata dan pengembangan ruang secara lebih efktif, sesuai dengan potensi dan daya dukungnya, partisipasi masyarakat yang optimal, dan tuntutan sigmentasi pasar tertentu. Enok, menyatakan bahwa "mata kuliah Geografi Pariwisata bertujuan supaya mahasiswa mampu memiliki wawasan pengetahuan, mengembangkan daya nalar, dan kreativitas mereka dalam menganalisis dan mengaplikasikan materi bahasan. Dengan demikian, untuk mencapai learning outcomes atau tujuan perkuliahan, maka dosen perlu mengembangkan kemampuan berfikir mahasiswa untuk mencapai tujuan perkuliahan tersebut.

Kemampuan berfikir mahasiswa yang ingin dikembangkan diperkuliahan ini adalah berfikir kreatif. Sitinjak, 2014 menyatakan bahwa seorang mahasiswa dikatakan berfikir kreatif bila ia bisa menemukan hal yang baru, yang baru bearti sesuatu yang bukan lazim dilakukan mahasiswa. Dalam mewujudkan berfikir kreatif, mahasiswa haruslah memiliki wawasan pengetahuan serta mampu mengembangkan daya nalar mereka dalam menganalisis permasalahan atau fenomena yang berkaitan dengan materi perkuliahan.

Kemampuan Berfikir kreatif sangat perlu dikembang pada setiap mahasiswa. Dengan mereka memiliki kemampuan berfikir kreatif, maka mahasiswa tidak sekedar mencapai tujuan perkuliah atau hasil belajar yang memuaskan, namun mereka juga dapat membekali dirinya dengan pengalaman nyata serta hasil karya baru yang bermanfaat bagi lingkungan sektar (manusia serta makhluk hidup lainnya). Utami (2009), menjelaskan bahwa dimensi kognitif dari kreativitas yaitu berpikir kreatif atau berpikir divergen mencakup kelancaran, kelenturan dan orisinalitas dalam berpikir.

Tomi (2012) mengemukakan bahwa "kemampuan berpikir kreatif itu meliputi kemampuan: 1) memahami informasi masalah, yaitu menunjukan apa yang diketahui dan apa yang ditanyakan, 2) menyelesaikan masalah dengan bermacam- 
macam jawaban (kefasihan), 3) menyelesaikan masalah dengan satu cara kemudian dengan cara lain dan siswa memberika penjelasan tentang berbagai metode penyelesaian itu (keluwesan), 4) memeriksa jawaban dengan berbagai metode penyelesaian dan kemudian membuat metode baru yang berbeda (kebaruan). Dengan demikian dapat disimpulkan bahwa ada empat komponen kemampuan berpikir kreatif. Keempat komponen tersebut adalah kefasihan, keaslian, keluwesan dan kebaruan. Empat komponen inilah yang akan menjadi tolok ukur kemampuan berpikir kreatif siswa.

Model pembelajaran Problem Solving dikembangkan oleh George Polya pada tahun 1887-1985. Model ini awalnya digunakan pada bidang matematika. Seiring dengan waktu, permasalahan dalam pembelajaran atau perkuliahan tidak sebatas pada bidang tersebut, namun juga pada bidang lainnya khususnya disaat ini ialah mata kuliah Geografi Pariwisata. Sesuai dengan pendapat George Polya yang menyatakan bahwa "if you can't solve a problem, then there is an easier problem you can't solve or find it" artinya apabila anda tidak dapat menyelesaikan problem, maka ada problem termudah yang tidak dapat anda selesaikan atau temukan. Dengan demikian, dapat dimaknai bahwa model ini dapat dipergunakan dalam bidang apapun jika memang diperlukan dalam hal menyelesaikan masalah.

Model pembelajaran Problem Solving memerlukan kemampuan berpikir dan memecahkan masalah. Maksudnya mahasiswa diberi tugas yang dihadapkan pada suatu permasalahan, kemudian diminta untuk memecahkannya. Menurut Suminto (2015) "model pembelajaran yang menggunakan masalah sebagai langkah awal dalam mengumpulkan dan mengintegrasikan pengetahuan baru".

Model ini dapat digunakan ketika dosen dan mahasiswa mempunyai keinginan untuk meraih sebuah tujuan tertentu dan tujuan itu belum tercapai. Patmani (2013) menyatakan bahwa "kemampuan mahasiswa dalam menyelesaikan masalah dapat tercermin dari kemampuan mahasiswa dalam menghadapi soal ujian, yang dapat digolongkan sebagai masalah". Sebagaimana dalam perkuliahan geografi pariwisata memiliki tujuan yakni meningkatkan kemampuan berpikir kreatif dalam mempelajari materi bahasan, maka dalam mewujudkan hal tersebut dosen memberikan tugas dalam jenis soal essay. 
Soal essay yang diberikan mencakup pertanyaan yang berkaitan dengan meteri perkuliahan khusus pokok bahasan permasalahan geografi pariwisata. Pada pokok bahasan ini, mahasiswa dituntut untuk mengembangkan kemampuan berpikir kreatif mereka dengan ciri-ciri menyebutkan, mengidentifikasi, merumuskan penyebab terjadi permasalahan, memberi hipotesis, serta menentukan solusi dari permasalahan yang sedang terjadi pada objek wisata di Kalimantan Barat. Dalam mengerjakan atau menyelesaikan soal/tugas yang diberikan dosen, maka mahasiswa dipandu dengan menggunakan langkahlangkah/sintak pembelajaran model pembelajaran Problem Solving.

Sintak/langkah-langkah model pembelajaran Problem Solving terdiri atas enam tahapan menurut Wankat dan Oreovoez (dalam Wena, 2012) yaitu sebagai berikut, tahapan 1: mengidentifikasi permasalah, tahap 2: merepresentasi atau menyajikan masalah, tahap 3: merencanakan pemecahan, tahapan 4: menereapkan atau mengimplementasikan perencanaan, tahap 5: menilai perencanaan, tahap 6: menilai hasil pemecahan.

Hasil penelitian yang serupa seperti Tomi, Irwan, dan Doni (2012) menyatakan bahwa "peningkatan kemampuan berpikir kreatif siswa yang belajar dengan model pembelajaran berbasis masalah lebih baik dari meningkatan kemampuan berpikir kreatif siswa yang diajarkan dengna pembelajaran konvevnsional". Selain itu, Adhetia (2016) menyatakann bahwa "Problem Solving dengan setting kooperatif tipe TAI dan pendekatan Problem Solving dengan setting kooperatif STAD, masing-masing lebih efektif daripada pendekatan konvensional ditinjau dari aspek prestasi belajar matematika dan self confidence siswa dalam pembelajaran matematika di SMP". Hasil penelitian tersebut dapat dijadikan acuan, walaupun ada beberapa vaiabel terikat yang tidak sama dengan penelitian ini. Namun perbedaan itu bukan menjadi penghalang bagi peneliti untuk melaksanakan penelitian ini. Justru perbedaan itu juga yang menjadi keunikan dalam penelitian eksperiment/uji coba ini serta yang membedakan antara peneliti satu dengan lainnya. 
Penelitian ini bertujuan untuk megetahui apakah ada pengaruh model pembelajaran problem solving terhadap kemampuan berfikir kreatif mahasiswa pada mata kuliah geografi pariwisata tahun akademik 2016/2017.

\section{METODE}

Penelitian ini merupakan Quasi Experiment (Eksperimen Semu). Rancangan penelitian yang dipilih adalah Nonequivalent Control Group Design. Berdasarkan rancangan tersebut, ditetapkan dua kelas penelitian tanpa acak. Kedua kelompok tersebut akan menjadi kelas eksperimen dan kontrol. Kelas eksperimen mendapatkan perlakuan menggunakan model pembelajaran problem solving. Kelas kontrol tidak diberikan perlakuan menggunakan model pembelajaran problem solving (pembelajarannya ceramah, diskusi dan tanya jawab). Selain dua kelas penelitian yang telah disebutkan, ada satu kelas lagi yang digunakan sebagai kelas uji coba dari instrumen yang akan diujikan untuk kelas eksperimen dan kontrol.

Rancangan penelitan tersebut mengacu pada model Nonequivalent control group design yang tertera pada tabel berikut.

Tabel 1. Model Rancangan Nonequivalent Control Group Design

\begin{tabular}{llll}
\hline Subjek & Kemampuan Awal & Perlakuan & Kemampuan Akhir \\
\hline A & $\mathrm{O}_{1}$ & $\mathrm{X}$ & $\mathrm{O}_{2}$ \\
$\mathrm{~B}$ & $\mathrm{O}_{1}$ & - & $\mathrm{O}_{2}$ \\
\hline
\end{tabular}

(Sumber Sugiyono, 2010)

Keterangan:

A $=$ Kelas Eksperimen

$\mathrm{B}=$ Kelas Kontrol

$\mathrm{O}_{1}=$ Tes awal (Pretest)

$\mathrm{O}_{2}=$ Tes akhir (Postest)

$\mathrm{X}=$ Perlakuan dengan model pembelajaran $P B L$

- $\quad$ = Tidak ada perlakuan (pembelajaran dengan ceramah, diskusi, dan tanya jawab) 
Data yang dikumpulkan dalam penelitian ini adalah data yang sesuai dengan fokus penelitian, yaitu tentang permasalahan pariwisata yang ada di Kalimantan Barat dengan menggunakan model pembelajaran problem solving terhadap kemampuan berfikir kreatif. Dalam penelitian kuantitatif, data berupa rangkaian angka. Jenis data dalam penelitian ini adalah data primer dan sekunder. Data primer diperoleh dalam bentuk verbal dan juga perilaku informan. Sedangkan data sekunder bersumber berupa foto-foto, dokumen, dan benda yang dapat digunakan sebagai pelengkap data primer tentang penggunaan model pembelajaran problem solving pada mahasiswa saat mata kuliah Geografi Pariwisata. Data primer dikelompokkan sesuai dengan sub fokus yang sudah ditentukan peneliti.

Adapun sumber data yang digali dalam penelitian ini terdiri dari sumber data utama yang berupa nilai IPK (KHS) mahasiswa, serta sumber data tambahan yang berupa transkip nilai pada semester 1 sampai dengan lima, serta sumber data tambahan yang berupa dokumen instrument dan fhoto. Adapun sumber data yang ada dalam penelitian ini dapat dibagi menjadi dua, yaitu: (a) Sumber data utama (primer), didapatkan melalui sistem informasi akademik dan bisa diminta dari petugas yang berwenang dibidang akademik (staf/pegawai Program studi Pendidikan Geografi atu Bagian Akademik) yang bisa memberikan nilai IPK (Kartu Hasil Semester) dan transkip nilai mahasiswa. (b) Sumber data tambahan (sekunder), yaitu sumber data, seperti buku dan majalah ilmiah, arsip, dokumen pribadi, dan dokumen resmi (Moleong, 2006).

Dalam buku lain disebutkan bahwa sumber-sumber sekunder terdiri atas berbagai macam, dari surat-surat pribadi, kitab harian, notula rapat perkumpulan, sampai dokumen-dokumen resmi dari berbagai instansi pemerintah. Sumber sekunder ini sesungguh kaya dan siap sedia menunggu penggunaanya oleh peneliti. (Nasution, 2006). Sember data sekunder dalam penelitian ini antara lain: informasi berkenaan dengan tingkat kemampuan akademik mahasiswa dikelas yang didapatkan melalua wawancara langsung dari mahasiswa pada kelas A dan B Pagi semester enam.

Subjek dalam penelitian ini adalah mahasiswa semester 6 (enam) kelas A Pagi dan B Pagi. Subjek ditentukan berdasarkan kemiripan rata-rata nilai IPK dari 
Transkip Nilai mulai semester 1 sampai dengan 5. Subjek penelitian untuk kelas eksperimen menggunakan A Pagi dengan jumlah siswa 35 orang dan B Pagi sebagai kelas kontrol dengan jumlah siswa 35 orang. Selain dua kelas tersebut, dipilih juga satu kelas sebagai kelas uji coba instrumen. Kelas yang digunakan sebagai uji coba adalah kelas A Sore yang sekarang telah sedang semester 8 dengan jumlah siswa 32 orang

Teknik pengumpulan data yang digunakan dalam penelitian ini, sebagai berikut: (1) Alat yang digunakan untuk mengumpulkan data dalam penelitian ini adalah tes essay. (2) Tes awal (pre test) adalah tes yang dilaksanakan sebelum kegiatan belajar mengajar dengan suatu perlakuan yang diberikan. Tes ini digunakan untuk mengetahui kemampuan berpikir kreatif awal mahasiswa sebelum perlakuan. (3) Tes akhir (post test) adalah tes yang dilakukan setelah pembelajaran selesai, tujuannya untuk mengetahui kemampuan berpikir kreatif mahasiswa setelah perlakuan baik pada kelas eksperimen maupun kelas kontrol.

Selanjutnya dihitung selisih data hasil pre test dan post test (gain score). Pengelompokan kemampuan berpikir kreatif menggunakan tabel Grounlund dan Lin (dalam Agustina, 2012) sebagai berikut.

Tabel 2. Pengkategorian Skor Berpikir Kreatif

\begin{tabular}{ll}
\hline Nilai Rata-Rata & Kategori \\
\hline$<20$ & Sangat kurang \\
$20-39$ & Kurang \\
$40-59$ & Sedang \\
$60-79$ & Baik \\
$80-100$ & Sangat baik \\
\hline
\end{tabular}

(Sumber: Grounlund dan Lin dalam Agustina, 2012)

Pengujian hipotesis dalam penelitian ini menggunakan t-test. Adapun tingkat signifikasi yang digunakan yaitu 5\%. Penghitungan analisis data menggunakan program SPSS 16.0 for Windows.

\section{HASIL DAN PEMBAHASAN}


Data dalam penelitian ini merupakan skor kemampuan berpikir kreatif mahasiswa geografi pada materi permasalahan pariwisata di Indonesia yang diperoleh melalui tes berbentuk essay. Tes essay digunakan sebagai alat pengumpul data yang berkenaan dengan indikator Kemampuan Berfikit Kreatif.

Data yang diperoleh melalui tes dan diproses sampai menghasilkan skor. Skor yang didapatkan dikelompokkan menjadi dua yaitu; (1) skor kemampuan berfikit kreatif mahasiswa kelas ekperimen menggunakan pembelajaran Problem Solving; (2) skor kemampuan berfikit kreatif mahasiswa kelas kontrol menggunakan pembelajaran konvensional (diskusi, tanya jawab dan penugasan). Skor yang diperoleh dihitung rata-ratanya. Kemudian skor dicari gain score nya dengan menghitung selisih antara skor kemampuan awal melalui pre test dan kemampuan akhir post test untuk pengujian hipotesis lebih lanjut.

Semua soal yang digunakan untuk mengukur Kemampuan Berfikit Kreatif Mahasiswa geografi telah diujicobakan terlebih dahulu Pada Mata Kuliah Geografi Pariwisata Tahun Akademik 2015/2016. Berdasarkan hasil uji coba instrument semua soal valid, reliabel dan memiliki TK serta DB yang baik, sehingga tidak perlu direvisi. Setelah diuji coba, maka 40 soal dapat digunakan untuk penelitian Kemampuan Berfikit Kreatif Mahasiswa geografi. Hasil penelitian berupa data kemdian dianalisis dengan menggunakan program SPSS 16.0 by Windows dengan independen sample $t$ test.. Berdasarkan hasil analisis pada model pembelajaran Problem Solving diperoleh data p-level lebih kecil dari $0,05(\mathrm{p}<0,05)$ yaitu dengan sig 0,00 . Rata-rata gain score kelas eksperimen yaitu 29,16 lebih besar dari kelas kontrol yang memiliki 12,15. Data tersebut menunjukkan bahwa pembelajaran dengan menggunakan model Problem Solving berpengaruh positif terhadap kemampuan berpikir kreatif mahasiswa.

\section{Kemampuan Berpikir Kreatif}

Pada penelitian ini terdapat sedikit perbedaan rata-rata skor pre test antara kelas eksperimen dengan kelas kontrol namun kedua kelas tersebut dianggap memiliki kemampuan yang hampir sama. Rata-rata skor kemampuan berpikir kreatif pre test untuk kelas eksperimen dan kontrol dapat dilihat pada tebel berikut. 
Tabel 3. Perbedaan Skor Kemampuan Berpikir Kreatif Pre test Kelas Eksperimen dan kelas Kontrol

\begin{tabular}{lll}
\hline Kelas & Pre Test & Kategori \\
\hline Eksperimen & 43,1 & Sedang \\
Kontrol & 47 & Sedang \\
\hline
\end{tabular}

Setelah diberikan perlakuan terdapat perbedaan skor rata-rata post test kelas eksperimen dengan kontrol. Perlakuan terhadap kelas eksperimen menggunakan model Problem Solving menjadikan rata-rata skor posttest lebih tinggi dibandingkan dengan kelas kontrol yang tidak menggunakan model Problem Solving . Skor post test untuk kelas eksperimen dan kontrol berturut-turut dalam penelitian ini termasuk kategori baik dengan nilai 72,3 dan sedang dengan nilai 59,3. Perbandingan nilai rata-rata kemampuan berpikir kreatif pre test dan post test dapat dilihat pada tabel berikut ini.

Tabel 4. Rata-Rata Nilai Kemampuan Berpikir Kreatif Pre Test dan Post Test

\begin{tabular}{llllll}
\hline Kelas & $\begin{array}{l}\text { Variabel } \\
\text { Pembelajaran }\end{array}$ & $\begin{array}{l}\text { Pre } \\
\text { Test }\end{array}$ & Kategori & Post Test & Kategori \\
\hline \multirow{2}{*}{ Eksperimen } & $\begin{array}{l}\text { Problem } \\
\text { Solving }\end{array}$ & 43,1 & Sedang & 72,3 & Baik \\
& Ceramah, & & & & \\
Kontrol & diskusi dan & 47 & Sedang & 59,3 & Sedang \\
& tanya jawab & & & & \\
\hline
\end{tabular}

Peningkatan kemampuan berpikir kreatif diperoleh dari skor pretest dan post test pada kelas eksperimen dan kontrol yang kemudian didapat gain score. Berdasarkan selisih nilai hasil pre test dan post test pada kelas eksperimen terhadap kemampuan berpikir kreatif mahasiswa diperoleh gain skor 29,2 sedangkan kelas kontrol 12,2. Adapun perbandingan nilai rata-rata kemampuan awal (pre test), kemampuan akhir (post test) dan gain score antara kelas Eksperimen dan kontrol dapat dilihat pada lampiran 13. 


\section{Kemampuan Berpikir Kreatif Tiap Indikator}

Indikator kemampuan berpikir kreatif pada penelitian ini terdiri dari empat indikator, yaitu: kemampuan berpikir lancar, kemampuan berpikir luwes, kemampuan berpikir orisinil serta kemampuan merinci. Keempat kemampuan ini mengalami peningkatan baik pada kelas eksperimen maupun kelas kontrol.

Tabel 5. Nilai Rata-rata Kemampuan Berpikir Kreatif Setiap Indikator

\begin{tabular}{llllll}
\hline Kelas & Indikator & Pre test & Kategori & Post test & Ketegori \\
\hline \multirow{5}{*}{ Eksperimen } & Berpikir lancar & 68,8 & Baik & 85 & Sangat baik \\
& Berpikir Luwes & 42,9 & Sedang & 87 & Sangat baik \\
& Berpikir Orisinil & 32,6 & Kurang & 67,9 & Baik \\
& Merinci & 21,7 & Kurang & 44,8 & Sedang \\
& Berpikir lancar & 73,1 & Baik & 83,3 & Sangat baik \\
\multirow{5}{*}{ Kontrol } & Berpikir Luwes & 47,2 & Sedang & 70,1 & Baik \\
& Berpikir Orisinil & 37 & Kurang & 49,5 & Sedang \\
& Merinci & 22,5 & Kurang & 27 & Kurang \\
\hline
\end{tabular}

Berdasarkan hasil analisis data skor kemampuan berpikir kreatif mahasiswa menunjukkan bahwa terjadi peningkatan perolehan rata-rata skor kelas eksperimen dari 43,1 menjadi 72,3 atau dengan peningkatan sebesar 29,2. Meskipun pada kelas kontrol juga mengalami peningkatan skor sebesar 12,2 atau dari 47,0 menjadi 53,3 namun jika dibandingkan dengan kelas eksperimen peningkatan rata-rata skor berpikir kreatif kelas eksperimen lebih tinggi. Selisih peningkatan skor kelas eksperimen dan kontrol adalah sebesar 17,0. Jadi, dapat disimpulkan bahwa pembelajaran dengan menggunakan model Problem Solving berpengaruh positif terhadap kemampuan berpikir kreatif mahasiswa. Hal ini dibuktikan dengan hasil perhitungan analisis uji t diperoleh data p-level lebih kecil dari $0,05(\mathrm{p}<0,05)$ yaitu 0,00 .

Jadi, penggunaan model pembelajaran Problem Solving memang terbukti selain berpengaruh juga berhasil dalam menumbuhkan kemampuan berpikir kreatif mahasiswa dengan menempatkan minimal pada kategori baik. 
Kemerataan peningkatan tiap indikator kemampuan berpikir kreatif ini diduga kuat disebabkan oleh teknik-teknik kreatif yang digunakan pada langkahlangkah model pembelajaran Problem Solving, meliputi: teknik dasar (pertanyaan terbuka dan sumbang saran), teknik analogi, dan teknik pemecahan masalah kreatif.

Secara umum penggunaan model pembelajaran Problem Solving telah terbukti berpengaruh terhadap kemampuan berpikir kreatif mahasiswa. Termasuk juga peningkatan setiap indikator berpikir kreatif secara keseluruhan. Akan tetapi terdapat kelemahan pada kelas eksperimen dan kelas kontrol pada indikator kemampuan merinci. Hal tersebut ditandai dengan skor pada indikator merinci kelas eksperimen yang hanya memperoleh rata-rata skor 44,8 dan termasuk kategori sedang. Pada kelas kontrol rata-rata skor 27 dan termasuk kategori kurang. Ini dimungkinkan karena sebelumnya mahasiswa tidak terbiasa dalam merinci suatu gagasan. Seperti terlihat pada nilai rata-rata skor sebelum adanya perlakuan yang tergolong pada kategori kurang. Dampaknya yaitu meskipun gagasan mahasiswa tergolong baik namun ketika merinci mahasiswa kurang mampu untuk mengoperasionalkan gagasan tersebut dalam bentuk tindakan nyata dan rinci.

\section{SIMPULAN}

Berdasarkan hasil analisis data dan pembahasan hasil penelitian dapat disimpulkan bahwa penggunaan model pembelajaran Problem Solving memberikan pengaruh positif terhadap kemampuan berpikir kreatif mahasiswa. Hal ini dibuktikan dengan hasil perhitungan analisis uji t mengunakan independen sample t test diperoleh data p-level lebih kecil dari 0,05 $(\mathrm{p}<0,05)$ yaitu 0,00 . Ratarata skor post test kelas eksperimen lebih tinggi dibandingkan kelas kontrol. Hal tersebut disebabkan oleh langkah-langkah model pembelajaran Problem Solving yang di dalamnya terdapat teknik-teknik belajar kreatif dari yang sederhana sampai yang kompleks. Selain itu faktor suasana dan proses pembelajaran di kelas juga mendukung hasil penelitian ini. 


\section{DAFTAR PUSTAKA}

Agustina, Sri. 2012. Pengaruh Problem Based Learning Terhadap Kemampuan Berpikir Kritis dan Kreatif Mahasiswa Universitas Kanjuruhan Malang Pada Matakuliah Hidrologi.Tesis.Tidak Diterbitkan. Malang: Program PascaSarjana UM.

Abu Ahmadi. 1992. Strategi Belajar Mengajar. Bandung: CV Pustaka Setia

Adhetia, Martyanti. 2016. Keefektifan Pendekatan Problem Solving Dengan Setting stad dan TAI ditinjau dari prestasi dan self-confidence. Jurnal riset pendidikan matematika volume 3 - nomor 1, Mei 2016, (1 - 15).

Arieti, Salvano. 1976. Creativity: The Magic Synthesis. New York: Mc Graw-Hill International Book Co

Berg, R. A. 2001. Social Constructions of Creativity in a Middle School Math Classroom. Tersedia: Online (http://www.jrrb.com/examples/Social_Const_Creativity.pdf). Diunduh pada tanggal 9 Mei 2008.

Boeree, C. G. 2013. Personality Theories. Yogyakarta: Prismasopie.

Blane dan Evans. 1989. Mathematics Course Development Support Material.

Buzan, T, and Buzan, B. 2004. The Power of Creativity Intelligence: Sepuluh cara jadi orang yang jenius kreatif. Alih bahasa oleh: Susi Purwoko. Jakarta: PT. Gramedia Utama.

Branca, N.A. (1980). Problem Solving as Goal, Process and Basic Skills. in S Krulik and R.E. Reys (Eds). Problem Solving in School Mathematics. Washington DC: NCTM.

Creswell, Jhon W. 2012. Educational Research, Planning, Conducting, and Evaluating Quantitative and Qualitative Research. Boston: Pearson.

Davis, G. A. (2012). Anak Berbakat dan Pendidikan Keberbakatan. Jakarta: PT Indeks.

De Bono, Edward. 1991. Lateral Thinking (Berpikir Lateral). Alih bahasa oleh Sutoyo. Jakarta: Airlangga..

Enok, Maryani, \& Bagja, Waluya. Tanpa Tahun. Silabus Geografi Pariwisata. Online (http://file.upi.edu/direktori/fpips/jur._pend._geografi/197210242001121 -bagja_waluya/geografi_pariwisata/sil_geo_pariwisata.pdf) 
Gagne. 2009. The condition of learning and theory of intruction (4 th edition). New York: Holt. Rainthat and Winston.

Guilford, J. P. 1981. Fundamental Statistics in Psychologi and Education. New York: Mc Graw-Hill International Book Co..

Hergenhanh, B.R. \& Olson, M.H. 2013. Personality Theories (Teori-Teori Kepribadian). Alih bahasa oleh: Yudi Santoro. Yoyakarta: Pustaka Pelajar.

Kesumah, W. 2011. Model-Model Pembelajaran. Online di http://wijayalabs.wordpress. com/2008/04/22/model-modelpembelajaran/

Krulik, S. \& Rudnick, J.A. 1999. Innovative Task to Improve Critical and Creative Thinking Skills. Dalam L.V.Stiff \& F.R. Crucio (Eds), Developing Mathematical Reasoning in Grades K-12. 1999 Yearbook (hal.138-145). Reston: The National Coucil of Theacher of Mathematic, Inc.

Patnani, Miwa. 2013. Upaya Meningkatkan Kemampuan Problem Solving Pada Mahasiswa. Jurnal Psikogenesis. Vol. 1, No. 2/ Juni 2013.

Pepkin. K, L. 2004. Creative Problem Solving in Matc.Online di hti.mat.uh.edu/curriculum/units/2000/02/00.02.04.pdf.

Polya, G.2004. How to Solve It. United State of America: Princenton University Press.

Made, Wena. 2009. Strategi Pembelajaran problem solving. Jakarta: PT. Bumi Aksara.

Maslow, A.H. 1968. Toward a Psycology of Being. York: Van Nortsran.

Moleong, Lexy J. 2007. Metodologi Penelitian Kualitatif. Bandung: Remaja Rosda Karya.

Muandar, Utami. 2009. Pengembangan Kreativitas Anak Berbakat. Jakarta: Rineka Cipta.

Munandar, S.C.U. (1987) Pengembangan Bakat dan Kreativitas Anak sekolah. Jakarta: Gramedia Pustaka Utama.

Munandar, S.C.U. (1999) Kreativitas \& Keberbakatan Strategi Mewujudkan Potensi Kreatif dan Bakat. Jakarta: Gramedia Pustaka Utama. 
Nasution. 2006. Berbagai Pendekatan Dalam Proses Belajar Mengajar. Jakarta: Bumi Aksara.

Olson, Robert W. 1996. The Art of Creative Thinking (Seni Berpikir Kreatif).Alih bahasa oleh Alfonsus. Jakarta: Airlangga.

Rawlingson, J.G. 1981. Creative Thinking and Brainstorming. New York: Halstead Press.

Semiawan, Cony dkk. 1987. Memupuk Bakat dan Kreativitas Siswa Sekolah Menengah: Petunjuk bagi Guru dan Orang Tua. Jakarta: PT Gramedia.

Siswono, Tatag Y.E. 2008. Proses Berpikir Kreatif Siswa Dalam Memecahkan dan Mengajukan Masalah Matematika. Jurnal Pendidikan Jilid 15, Nomor 1, 60-68.

Slameto. 1995. Belajar dan Faktor-Faktor yang Mempengaruhinya. Jakarta: Rineka Cipta.

Solso, R. L. 2007. Psikologi Kognitif. Jakarta: Erlangga.

Suharnan. 2011. Kreativitas Teori dan Pengembangan. Surabaya: Laros.

Sukoriyanto. 2001. Langkah-langkah dalam Pembelajaran Ilmu pengetahuan sosial dengan Menggunakan Penyelesaian Masalah. Jurnal Ilmu pengetahuan sosial atau Pembelajarannya. Tahun VII. No. 2. 103-110.

Sugiyono, 2010. Metode Penelitian Pendidikan. Bandung: Alfabeta

Suminto. 2015. Penerapan Model Pembelajaran Kooperatif Tipe Problem Solving Pada Materi Pokok Lingkaran. Jurnal e-DuMath Volume 1 No. 1 , $\begin{array}{llll}\text { Januari } & 2015 & \text { Hlm. } & \text { Online }\end{array}$ (http://download.portalgaruda.org/article.php?article=293390\&val=6368 \&title=enerapan $\% 20$ model\%20pembelajaran $\% 20$ kooperatif\%20\%20tipe $\% 20$ problem\%20solving\%20pada\%20materi\%20\%20pokok\%20lingkara n).

Tomi, Tridaya, Putra.I, \& Dodi, Vionanda. 2012. Meningkatkan kemampuan berpikir kreatif siswa dengan pembelajaran berbasis masalah. Vol. 1 no. 1 (2012) : Jurnal Pendidikan Matematika, Part 3 : Hal. 22-26.

Utami, Munandar. 2009. Pengembangan Kreativitas Anak Berbakat. Jakarta: Rineka Cipta. 